\title{
Nutritional analysis of Rhazya stricta collected from different sites of Kalabagh, Mianwali, Pakistan
}

\author{
Asifa Sameen ${ }^{1}$, Huma Akbar ${ }^{1 *}$, Rabia Bashir ${ }^{1}$, Aneela Sharif ${ }^{1}$, Fareeda \\ Yasmeen $^{2}$ and Muhammad Raza Khan ${ }^{3}$ \\ 1. Department of Biological Sciences, University of Mianwali, Punjab-Pakistan \\ 2. Department of Botany, University of Agriculture Faisalabad, Punjab-Pakistan \\ 3. Department of Wildlife, PMAS Arid Agriculture university, Rawalpindi Islamabad, Punjab-Pakistan \\ *Corresponding author's email: humaofficial@gmail.com
}

Citation

Asifa Sameen, Huma Akbar, Rabia Bashir, Aneela Sharif, Fareeda Yasmeen and Muhammad Raza Khan.

Nutritional analysis of Rhazya stricta collected from different sites of Kalabagh, Mianwali, Pakistan. Pure and Applied Biology. Vol. 9, Issue 4, pp2285-2296. http://dx.doi.org/10.19045/bspab.2020.90243

\begin{tabular}{llll}
\hline \hline Received: 13/03/2020 & Revised: 12/06/2020 & Accepted: 20/06/2020 & Online First: 08/07/2020
\end{tabular}

\section{Abstract}

Medicinal plants have constantly played significant parts in fields of culture, medicine and nutrition. Rhazya stricta is a small, upright perennial, poisonous shrub. Different plant parts have been used in medicine traditionally in contradiction of many diseases like diabetes, skin diseases, foot burning, stomach pain. The aim of research work was to study different nutrient composition in Rhazya stricta collected from different sites of Kalabagh, Mianwali. By using AOAC standard methods moisture content, fat content, fiber and protein content were checked. Proximate analysis showed plant besides having medicinal importance plant have moderate nutritional composition. There is little variation in nutrients of Rhazya stricta collected from different sites because of little variation in quality of soil and climatic conditions. It is concluded that medicinal plants should also be studied for their nutritional composition beside medicinal importance.

Keywords: Kjeldhal method; Medicinal Plants; Mianwali; Proximate analysis; Rhazya stricta

\section{Introduction}

Medicinal plants have constantly played significant parts in fields of culture, medicine and nutrition. Medicinal plants are considered as basic bio resources of traditional and modern medicines because they provide valuable bioactive compounds used in preparation of drugs [1]. Approximately, sixty percent of the world population and eighty percent of the developing countries population rely upon medicinal plants for their basic healthcare demands [2]. Over the centuries, humans have depended on plants for basic requirements such as food, shelter, clothing, and poisons for hunting or murder, hallucinogens, stimulants and medicines [3]. These plants also have been regarded important for research, transport, commercial purposes and income. According to an estimate, $12 \%$ of Pakistani flora is used to cure many diseases but attention has never been given to preserve or improve cultivation of these plants [4].For the physiological functions of body each plant has nutritional value and also has medicinally important phytochemicals. Bio chemicals sugars, 
proteins, fats and nutrients have vital role in supporting man needs for life [5].

Kalabagh is prominent for red Salt hills, Indus River and Kalabagh dam. Topography is combination of hills and semi-arid planes from underlying rocks limestone and sandstone detritus have given characteristics to the soil of area. Soil is fertile in quality, nearest to Indus River. Due to alluvial deposits from Indus and surrounding hills soil is loamy and area is semi-arid. Vegetation is unique due to diverse habitat, soil composition and topography. The forest range includes Kalabagh, Kundian and Kachha forest near Indus River. Mianwali and Kalabagh hills are facing the pressures of overgrazing because all kinds of livestock grazed in these hills. Since the area is hilly and plain type of land, overgrazing is more damaging in plains than hilly areas $[6,18,31]$. Rhazya stricta is a small, upright perennial, poisonous shrub. The name Rhazya was given to species after the name $\mathrm{Abu} B \mathrm{Bkr}$ Mohammed bin Zakariya Ar-Razi a Muslim scientist and its Latinized name is Rhazes famous in Europe in Arabic, it is also known as "Harmal" in Urdu. Rhazya stricta is present in many areas of World and in sandy plains of Saudi Arabia. Rhazya is abundantly found in western Asia and North Western parts of sub- continent Different plant parts have been used in medicine traditionally in contradiction of many diseases like diabetes, skin diseases, foot burning, and stomach pain. Plant is used mostly in the form of powder in traditional medicine. Body pain and chronic rheumatism. Acne and pimples are treated by Powder of dried fresh leaves [7].

Proteins play a significant role in metabolic activities and act as the building block of all cells, bones and muscles. Amino acids serve as donors in the synthesis of non-protein and nitrogen-containing compounds, including nucleotides, heme, creatine, choline and other substances [8]. Carbohydrates are commonly classified as monosaccharides, disaccharides, oligosaccharides and polysaccharides. Plants produce carbohydrates by photosynthesis. They act as body's main source of energy. They are involved in the responses to various stresses and serve as metabolic signs that accelerate hormone signal transduction pathways [9]. Fats are utilized in synthesis of hormones and steroids. They additionally act as solvents for fat-soluble vitamins and hormones. Fats have the largest caloric content and give the greatest measure of energy when consumed [10]. Crude fiber contains mostly of cellulose $(60 \%-80 \%)$, lignin $(4 \%-6 \%)$ and a few minerals. They have several medical advantages, including maintenance of gastrointestinal health, laxation and decreased danger of cancer, cardiovascular ailments, constipation, hemorrhoids and glucose modulation [11].

\section{Aim}

The aim of this research work was to study the biochemical attributes of most common medicinal plant in hilly area of Mianwali.

\section{Objectives}

To study medicinal importance of Rhazya stricta collected from different sites of Mianwali.

To evaluate phytochemical contents of Rhazya stricta collected from different sites of Mianwali.

\section{Materials and methods}

Survey was done to study most frequently used medicinal plant in hilly areas of Mianwali. In these surveys different plant species were observed and survey was done under the guidance of expert research supervisor and with the help of local people

\section{Sampling sites}

Samples were collected from different sites. Site selection was done on the basis of difference in soil composition, vegetation type (Fig. 1-6 \& Table 1). 


\section{Sample collection}

Soil sampling was done at five sites. Ten samples were taken randomly from each site. Samples Z scheme was used for soil sampling. 3 replicates were taken from each site.

\section{Sample preparation}

Soil Sample was made by mixing 3 replicates from homogenized soil. To study \% saturation paste of dry sample was made.

\section{Analysis of soil}

Soil texture was determined by Hygrometer method [12]. Electrical conductivity, $\mathrm{pH}$ and ions were checked according to $[13,14]$.

\section{Proximate analysis}

Proximate analysis such as moisture content, ash content, crude protein, crude fiber, crude fat and carbohydrates was conducted by the methods described in [15].

\section{Determination of moisture content}

$2 \mathrm{~g}$ of each leaf sample was taken in a petri dish and fully dried in an oven at $100^{\circ} \mathrm{C}$ for about six hours. After drying, samples were cooled in a desiccator and weighed once more. Moisture content (\%) was measured from the loss in weight of sample accordant with the formula:

Moisture loss $(\mathrm{g})=$ Original weight of sample $(\mathrm{g})$ - Weight of dried sample $(\mathrm{g})$

$$
\text { Moisture }(\%)=\frac{\text { Moisture loss }(\mathrm{g})}{\text { Original weight of sample }(\mathrm{g})} \times 100
$$

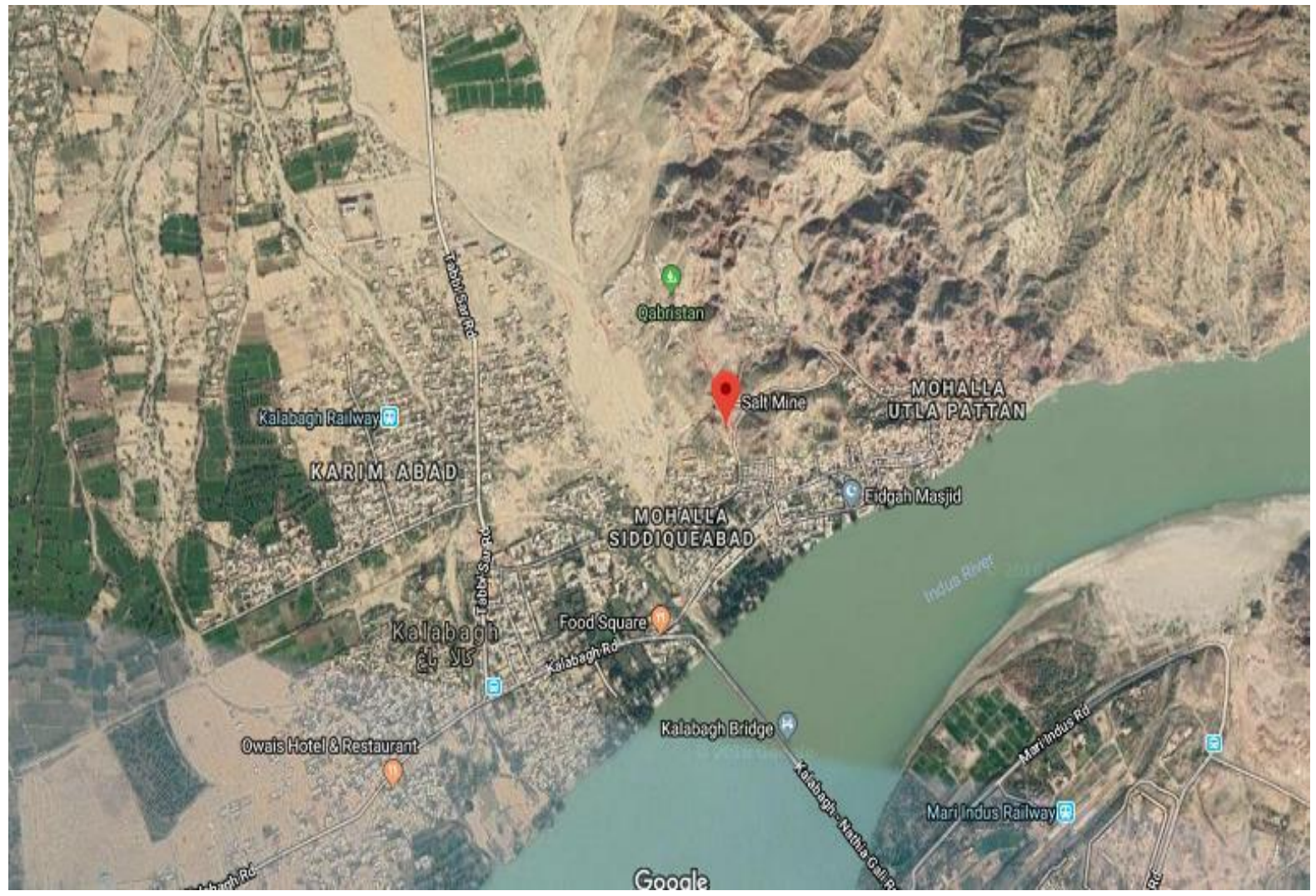

\section{Figure 1. Map of Kalabagh (Mianwali)}



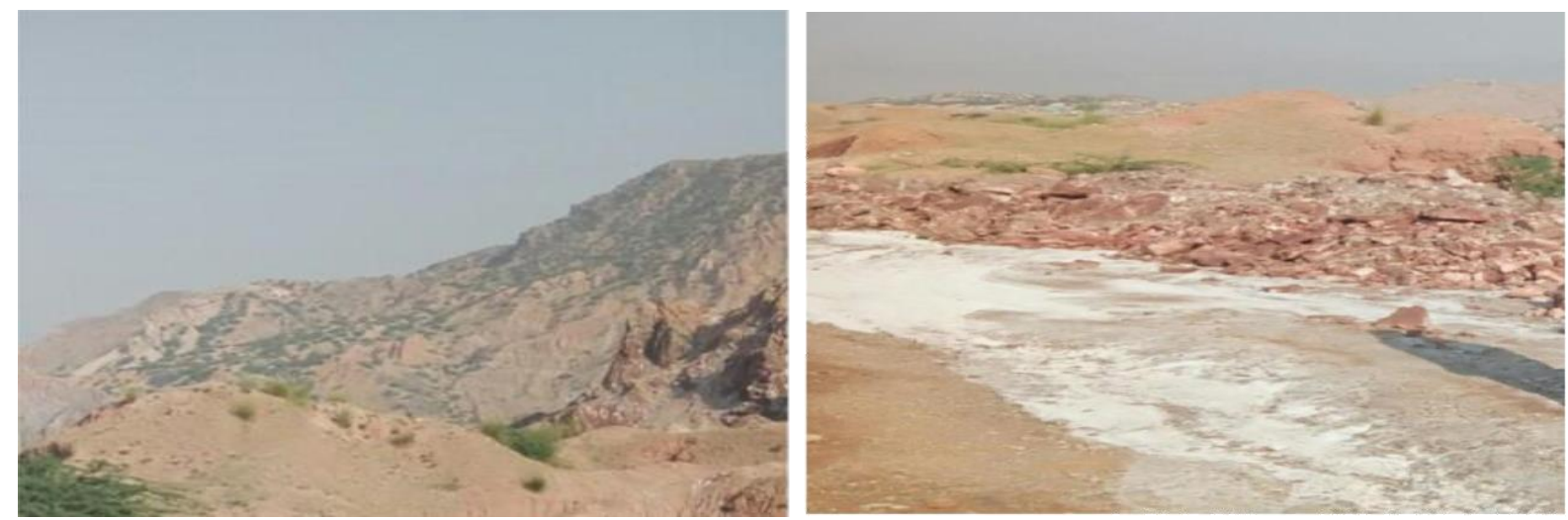

Figure 2. Site I

Figure 3. Site II
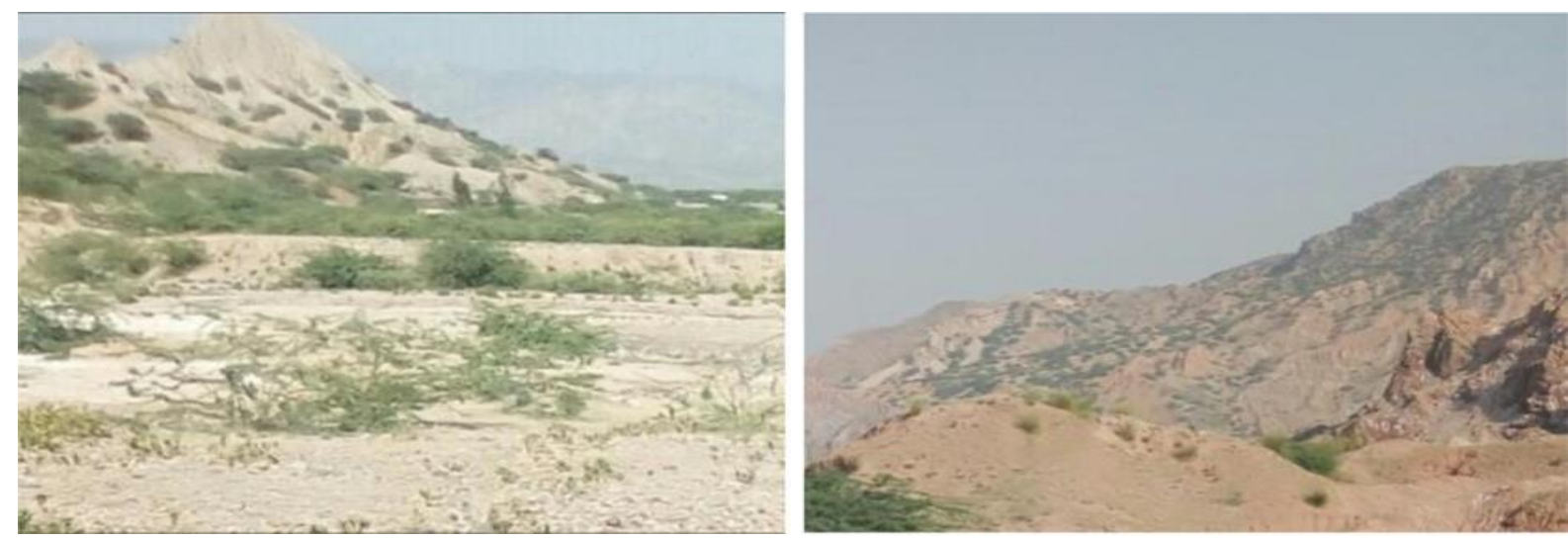

Figure. 4 Site III

Figure. 5 Sites IV

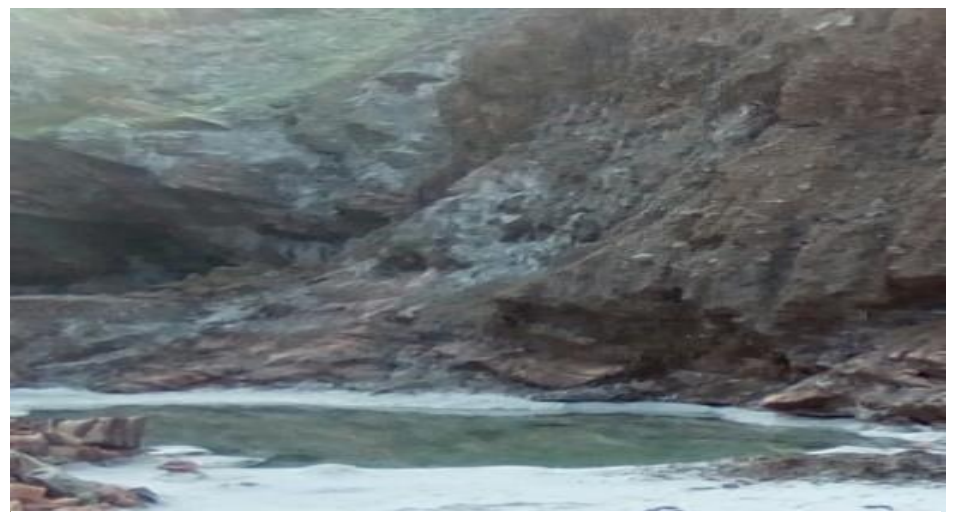

Figure. 6 Sites V

Table 1. Physiochemical properties of soil

\begin{tabular}{|c|c|c|c|c|c|}
\hline & Site 1 & Site 2 & Site 3 & Site 4 & Site 5 \\
\hline $\mathbf{p H}$ & 8.2 & 8.2 & 8.2 & 8.1 & 8.0 \\
\hline E.C mScm-1 $_{\text {Saturation\% }}$ & 2.48 & 2.95 & 3.76 & 3.08 & 2.71 \\
\hline Organic Matter\% & 38 & 38 & 38 & 38 & 38 \\
\hline Texture & 0.69 & 0.83 & 0.76 & 0.69 & 0.76 \\
\hline
\end{tabular}




\section{Determination of Ash content}

Ash content was estimated by keeping $2 \mathrm{~g}$ of each sample in a pre-weighed crucible and burnt on low flame. Samples were incinerated in a muffle furnace for 6 hours at $550^{\circ} \mathrm{C}$ till a constant weight was attained. Crucibles were cooled in a desiccator and weighed once more. Ash content (\%) was determined by subsequent formula:

$$
\text { Ash }(\%)=\frac{\text { Weight of ash }(\mathrm{g})}{\text { Weight of sample taken }(\mathrm{g})} \times 100
$$

\section{Determination of crude protein Reagents used} $\mathrm{H}_{2} \mathrm{SO}_{4}, \mathrm{~K}_{2} \mathrm{SO}_{4}, \mathrm{CuSO}_{4}, \mathrm{FeSO}_{4}, 40 \% \mathrm{NaOH}$, $4 \%$ boric acid and methyl red indicator.

By applying Kjeldahl's method, organic nitrogen and crude protein content present in leaf samples were estimated. Initially $1 \mathrm{~g}$ of each dried sample was digested in digestion flask with $20 \mathrm{~mL}$ concentrated sulphuric acid in the presence of $5 \mathrm{~g}$ digestion mixture $\left[\mathrm{K}_{2} \mathrm{SO}_{4}(90 \mathrm{~g})+\mathrm{CuSO}_{4}(7 \mathrm{~g})+\mathrm{FeSO}_{4}(3 \mathrm{~g})\right]$ for 3-4 hours on heating device until clear/green solution acquired. Digested material was diluted to $250 \mathrm{ml}$ and its $10 \mathrm{ml}$ was distilled with $10 \mathrm{ml} \mathrm{NaOH}$ (40\% solution) in micro Kjeldahl apparatus. Ammonia $\left(\mathrm{NH}_{3}\right)$ thus released was assembled in a receiver having $10 \mathrm{ml}$ of $4 \%$ boric acid solution by using methyl red indicator (1 drop/10mL). For determination of nitrogen, the content in the receiver was titrated against $0.1 \mathrm{~N} \mathrm{H}_{2} \mathrm{SO}_{4}$ until a golden-brown endpoint obtained. Nitrogen \%age was calculated by using following formula;

$$
\text { Nitrogen }(\%)=\frac{\text { Titre of } \mathrm{N} / 10 \mathrm{H}_{2} \mathrm{SO}_{4}}{\text { Weight of sample } \times \text { Volume of aliquot sample }}
$$

Crude protein content $(\%)$ was measured by multiplying nitrogen percentage with factor of 6.25 .

Crude Protein $(\%)=\%$ Nitrogen $\times 6.25$

Determination of crude fat content

\section{Reagent used}

Petroleum ether.

$2 \mathrm{~g}$ dried leaves sample, taken in a preweighed filter paper, was kept in extraction thimble of Soxhlet apparatus covered with a cotton plug. $250 \mathrm{ml}$ petroleum ether was added in it and heated. Fat was extracted in Soxhlet extractor at a rate of 3-4 drops per second of petroleum ether for about four hours. Then, the samples were removed from the apparatus and dried in an oven or on a hot plate oven for 5-10 minutes at a temperature of $70-90^{\circ} \mathrm{C}$. Samples were cooled in a desiccator and weighed. Formula used to estimate fat content present in a sample was; Crude Fat $(\mathrm{g})=\mathrm{W}_{1}-\mathrm{W}_{2}$

Where, $\mathrm{W}_{1}=$ Weight of sample before fat removal $\mathrm{W}_{2}=$ Weight of sample after fat removal
Crude fat content (\%) was estimated by following formula;

Fat $(\%)=\frac{\text { Weight of fat in sample }(\mathrm{g})}{\text { Weight of sample }(\mathrm{g})} \times 100$

\section{Determination of crude fiber \\ Reagents used}

$\mathrm{H}_{2} \mathrm{SO}_{4}, \mathrm{NaOH}$, distilled water $2 \mathrm{~g}$ moisture and fat free plant sample was taken in a 1000 $\mathrm{ml}$ beaker. $200 \mathrm{ml}$ of diluted (1.25\%) $\mathrm{H}_{2} \mathrm{SO}_{4}$ was added into it. The sample was digested by boiling for 30 minutes. Later, a cotton cloth was used to filter it; residue was washed with hot water until it was acid free. Again, the residue was poured into a $1000 \mathrm{ml}$ beaker and $200 \mathrm{ml}$ of diluted $(1.25 \%) \mathrm{NaOH}$ was added and boiled for 30 minutes. To make it alkali free, it was filtered and washed with hot distilled water. Residues were then transferred to a pre-weighed crucible and dried in an oven at $70-80^{\circ} \mathrm{C}$ overnight until constant weight obtained. Finally, the residues were charred on burner and ignited 
in muffle furnace at $550^{\circ} \mathrm{C}$ for 5-6 hours, cooled in desiccator and weighed again. Crude fiber percentage was measured as:

Crude fiber $(\%)=\frac{\mathrm{W}_{1}-\mathrm{W}_{2}}{\mathrm{~W}_{3}} \times 100$

Where,

$\mathrm{W}_{1}=$ Weight of dried sample $(\mathrm{g})$

$\mathrm{W}_{2}=$ Weight of the ignited sample $(\mathrm{g})$

$\mathrm{W}_{3}=$ Weight of the sample taken for analysis (g)

Determination of Carbohydrates (Nitrogen free extract)

Carbohydrate of each sample was measured by subtracting percentages of moisture content, ash content, crude protein, crude fat and crude fibers from 100 as follows;

$\operatorname{NFE}(\%)=100-($ moisture $\%+$ crude protein $\%+$ crude fat $\%+$ crude fiber $\%+$ ash $\%$ )

Statistical analysis

Statistical Program for Social Sciences (SPSS 16) was used for Statistical analysis. The significance of mean was at $0.001,0.01$ and 0.05 probability levels as recommended by [16].

\section{Results and discussion}

\section{Proximate analysis}

Proximate Analysis is dividing of compounds in a food into six types based on the chemical properties of the compounds. The six types are Moisture, Ash, Crude protein, Crude Fiber, Fat, and Carbohydrates.

Moisture \% in Rhazya stricta

Analysis of variance moisture in Rhazya stricta was explained (Table 2). Maximum concentration was observed at Site 3 (35.76 $\%)$ whereas minimum contents of moisture were observed in Site $5(32.04 \%)$. The decreasing order of moisture content was S2>S1>S3>S4>S5. The results of (Fig. 7) in current investigations were lower than the results reported by [17] and higher than the values reported by $[6,18]$. Shelf life and viability of microorganism's growth have been determined by moisture content [19].

Table 2. Analysis of variance of Moisture \% in Rhazya stricta collected from different sites of Kalabagh Mianwali

\begin{tabular}{|c|c|c|}
\hline Source of Variation(S.O.V) & Degree of Freedom (df) & Mean Square Moisture \\
\hline Sites & 4 & $6.941^{\text {ns }}$ \\
\hline Error & 10 & 3.300 \\
\hline
\end{tabular}

$\mathrm{ns}=$ non-significant $(\mathrm{P}>0.05)$

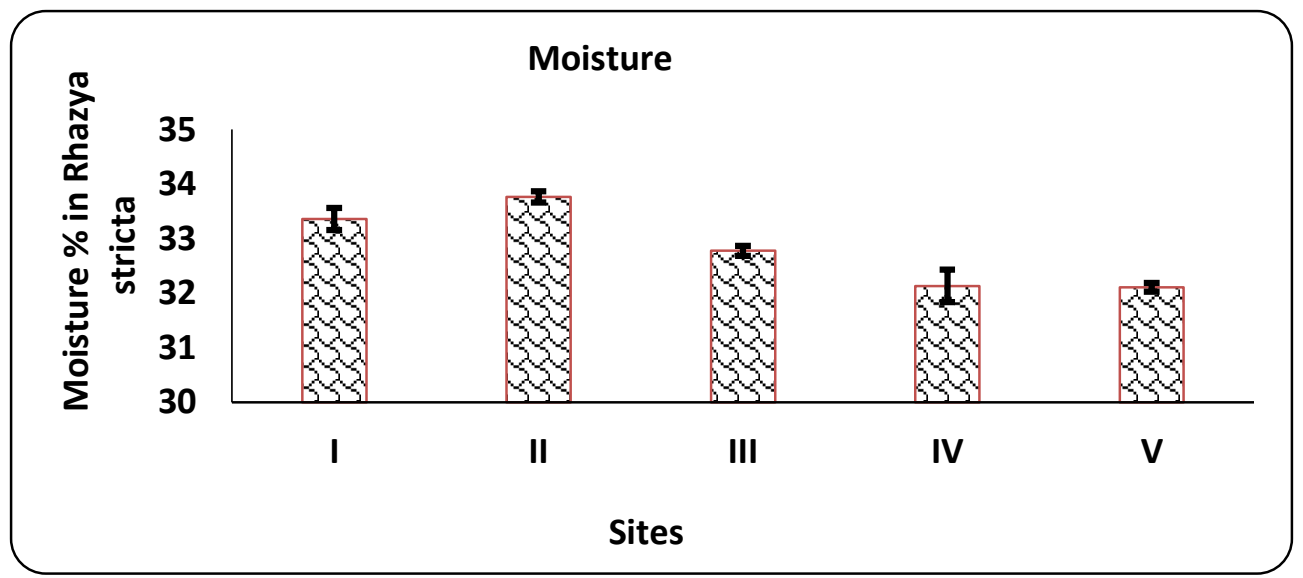

Figure 7. Moisture content (\%) in Rhazya stricta collected from different sites of Kalabagh Mianwali 
Ash \% in Rhazya stricta

Analysis of variance of ash in Rhazya stricta was explained (Table 3). Maximum concentration was observed at Site $4(6.042$ $\%)$ whereas minimum contents of ash were observed in Site 3 ( $4.943 \%)$. The decreasing order of ash content was $\mathrm{S} 4>\mathrm{S} 5>\mathrm{S} 1>\mathrm{S} 2>\mathrm{S} 3$ (Fig. 8) Results in present investigations were lower than values reported by [20] and in accordance with the values reported by [21]. High amount of ash suggested high amount of mineral elements $\mathrm{K}, \mathrm{Ca}$ and $\mathrm{Fe}$ [22].

Table 3. Analysis of variance of Ash \% in Rhazya stricta collected from different sites of Kalabagh Mianwali

\begin{tabular}{|c|c|c|}
\hline Source of Variation (S.O.V) & Degree of Freedom (df) & Mean Square Ash \\
\hline Sites & 4 & $0.583^{\text {ns }}$ \\
\hline Error & 10 & 0.278 \\
\hline
\end{tabular}

ns= non-significant $(\mathrm{P}>0.05)$

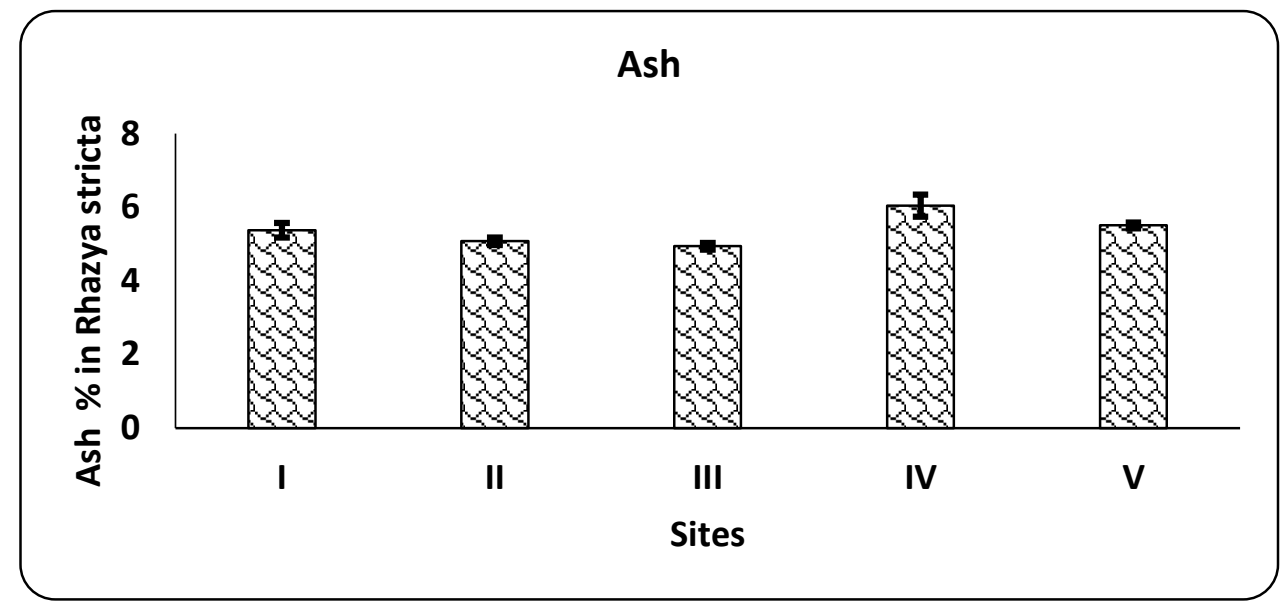

Figure 8. Ash (\%) in Rhazya stricta collected from different sites of Kalabagh Mianwali

Fat \% in Rhazya stricta

Analysis of variance of fat in Rhazya stricta was explained (Table 4). Maximum concentration was observed at Site $4(3.82 \%)$ whereas minimum contents of fat were observed in Site 1(3.04\%). The decreasing order of fat contents was $\mathrm{S} 4>\mathrm{S} 5>\mathrm{S} 3>\mathrm{S} 2>\mathrm{S} 1$
(Fig. 9). Results in present investigations had lower values than the findings reported by [23] and in accordance with the values reported by [24]. Diets with high fat add lipids to the diet, many functions of our body depend upon lipids $[21,25]$.

Table 4. Analysis of variance of Fat \% in Rhazya stricta collected from different sites of Kalabagh Mianwali

\begin{tabular}{|c|c|c|}
\hline Source of Variation (S.O.V) & Degree of Freedom (df) & Mean Square Fat \\
\hline Sites & 4 & $0.331^{\text {ns }}$ \\
\hline Error & 10 & 0.002 \\
\hline
\end{tabular}

ns $=$ non-significant $(\mathrm{P}>0.05)$ 


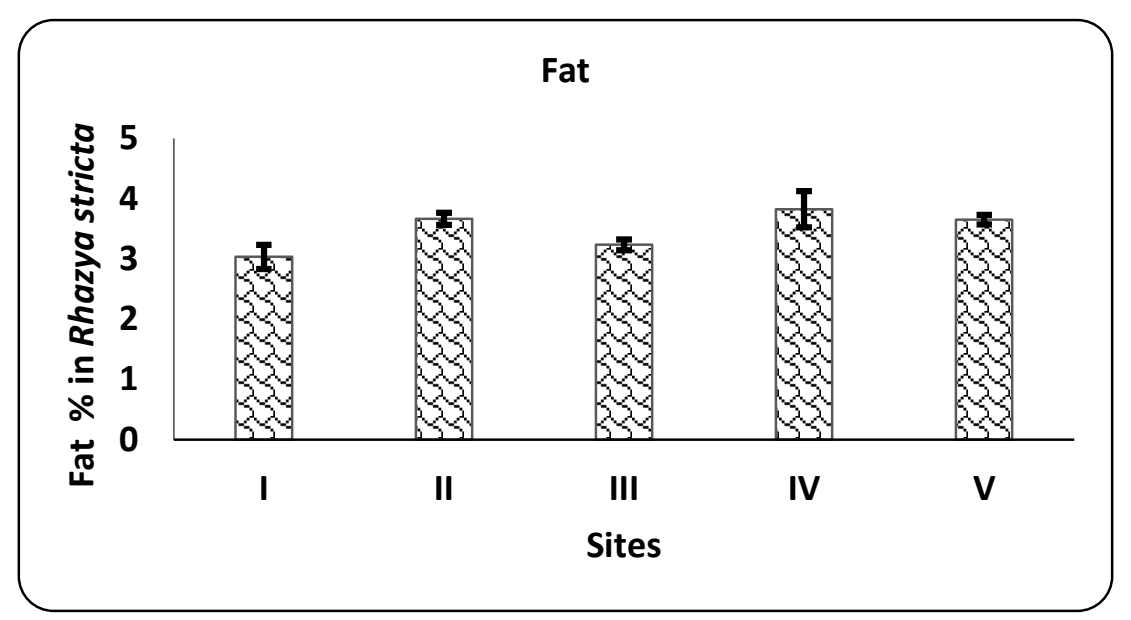

Figure 9. Fat content (\%) in Rhazya stricta from different sites of Kalabagh Mianwali

Crude Fiber \% in Rhazya stricta

Analysis of variance of crude fiber in Rhazya stricta was explained (Table 5). Maximum contents of fiber were observed at Site 5 $(12.237 \%)$ whereas minimum contents of fiber were observed in Site $2(11.80 \%)$. The decreasing order of crude fiber was
$\mathrm{S} 4>\mathrm{S} 5>\mathrm{S} 1>\mathrm{S} 2>\mathrm{S} 3$ (Fig. 10) Results in present investigations were higher than [19, 26] and same with the values reported by [20, 27]. For the prevention of heart diseases, colon cancer, and diabetes crude fiber is helpful $[24,28]$.

Table 5. Analysis of variance of Crude Fiber \% in Rhazya stricta collected from different sites of Kalabagh Mianwali

\begin{tabular}{|c|c|c|}
\hline Source of Variation (S.O.V) & Degree of Freedom (df) & Mean Square Crude Fiber \\
\hline Sites & 4 & $0.096^{\mathrm{ns}}$ \\
\hline Error & 10 & 0.466 \\
\hline
\end{tabular}

ns= non-significant $(\mathrm{P}>0.05)$

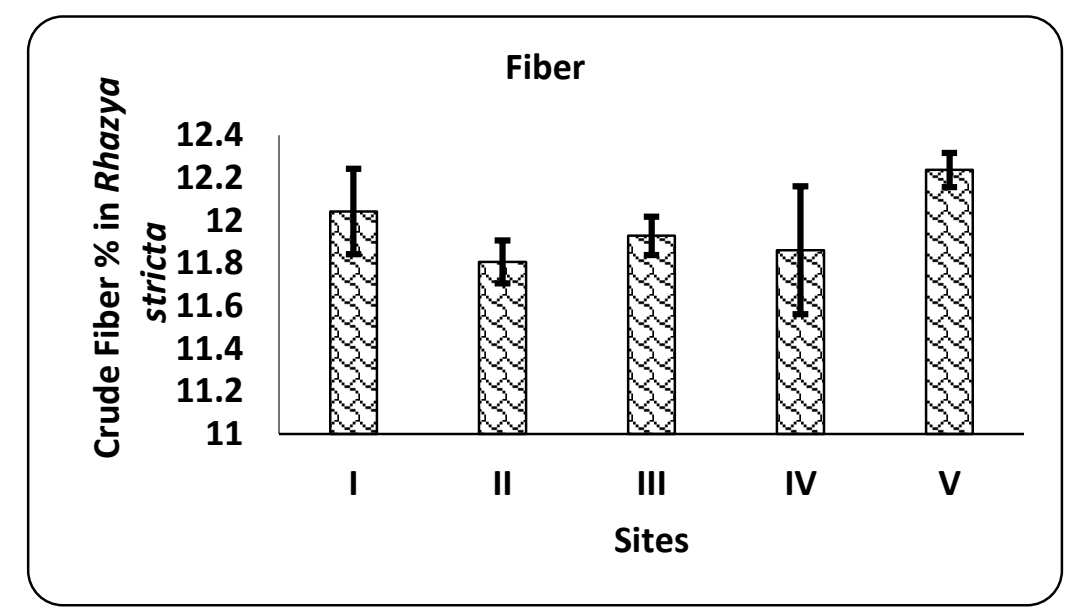

Figure 10. Crude Fiber content $(\%)$ in Rhazya stricta from different sites of Kalabagh Mianwali 
Crude Protein \% in Rhazya stricta Analysis of variance of protein in Rhazya stricta was showed (Table 6). Maximum contents were observed at Site $4(9.113 \%)$ whereas minimum contents of protein were observed at Site $2(8.15 \%)$. The decreasing order of crude protein content was
S4 $>$ S5 $>$ S1 $>$ S2 $>$ S3 (Fig. 11). Results in present investigations were lower than the values reported by $[21,25,29]$ and $[20,27$, $30]$. Higher values were reported by $[6,18$, 31]. The quality of proteins in plants is not good but on combining with animal protein gives adequate nutritional value [32].

Table 6. Analysis of variance of Crude Protein \% in Rhazya stricta collected from different sites of Kalabagh Mianwali

\begin{tabular}{|c|c|c|}
\hline Source of Variation & Degree of Freedom & Mean Square \\
\hline (S.O.V) & (df) & Crude Protein \\
\hline Sites & 4 & $0.453^{*}$ \\
\hline Error & 10 & 0.512 \\
\hline
\end{tabular}

$*$ Significant $(\mathrm{P}<0.05)$

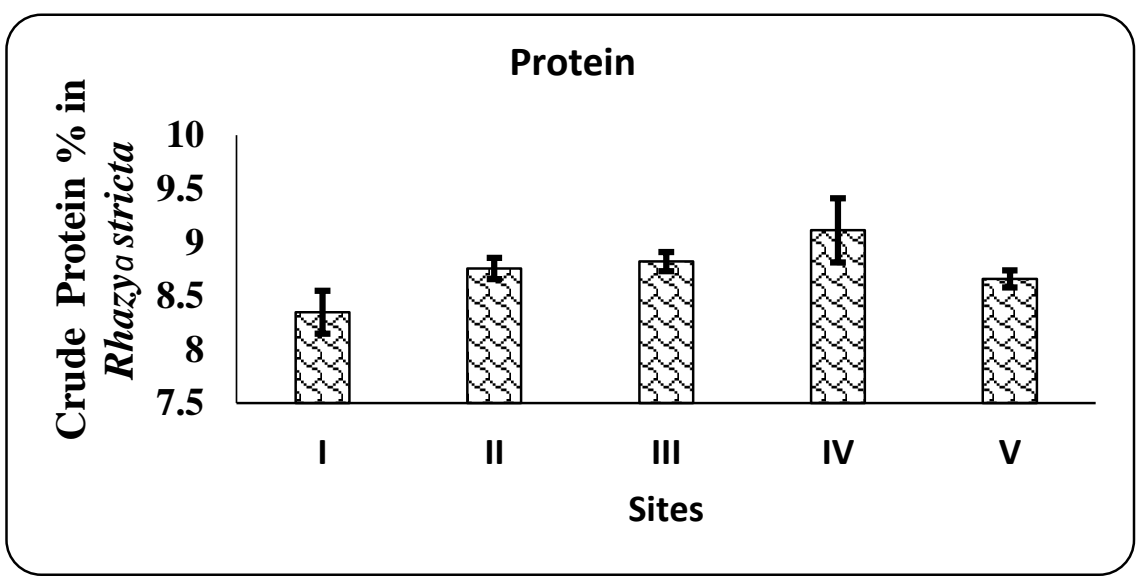

Figure 11. Crude Protein (\%) in Rhazya stricta collected from different sites of Kalabagh Mianwali

Carbohydrates \% in Rhazya stricta Analysis of variance of carbohydrates in Rhazya stricta was explained (Table 7). Maximum \%\%age was observed at Site 3 (38.89 \%) whereas minimum \%age carbohydrates were observed at Site $2(35.58$ $\%)$. The decreasing order of carbohydrates was as follows S3>S5>S1>S4>S2 (Fig. 12). Current results have low values than the values reported by $[20,24,27,28,30,33,34]$. Carbohydrates are energy giving nutrient provides accessible fuel for body functions $[19,26,35]$.

Table 7. Analysis of variance of Carbohydrates \% in Rhazya stricta collected from different sites of Kalabagh Mianwali

\begin{tabular}{|c|c|c|}
\hline Source of Variation (S.O.V) & Degree of Freedom (df) & $\begin{array}{c}\text { Mean Square } \\
\text { Carbohydrates }\end{array}$ \\
\hline Sites & 4 & $4.569^{*}$ \\
\hline Error & 10 & 4.594 \\
\hline
\end{tabular}

$*$ = Significant $(\mathrm{P}<0.05)$ 


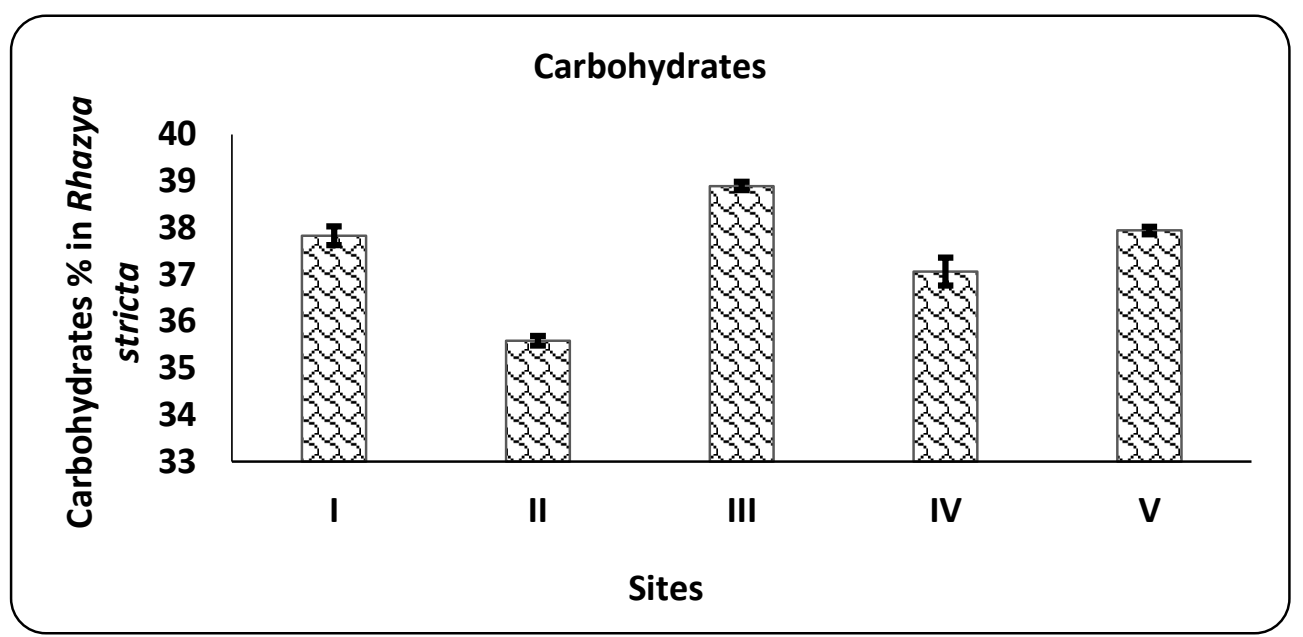

Figure 12. Carbohydrates (\%) in Rhazya stricta collected from different sites of Kalabagh Mianwali

\section{Conclusion}

From present study it was concluded that Rhazya stricta have moderate nutritional composition besides having medicinal importance. Medicinal plants should also be studied for their nutritional value. Present results will determine the nutritional composition of the plant so further studies should be done on nutritional composition of medicinal plants.

\section{Acknowledgement}

Every honor is due to Allah Almighty. The supreme, the ubiquitous ,the compassionate, the most merciful and the beneficent, Who knows the hidden facts of universe and we do not encompass anything of His knowledge except as He wills, His throne extends over the heavens and the earth and Who blessed me with the ability to do this work and thanks to the Holy Prophet Hazrat Muhammad (Peace Be Upon Him) and His AAL, Who has enabled me to know my Creator and lead me to the right path and save me to astray from the faithful tract, without His teachings and perfect life I was nothing but he leads this dirt-made nonentity.

\section{Authors' contributions}

Conceived and designed the experiments: A Sameen, Performed the experiments: A
Sameen, R Bashir \& F Yasmin, Analyzed the data: H Akbar, A Shareef \& R Bashir, Contributed materials/ analysis/ tools: MR Khan \& F Yasmeen, Wrote the paper: A Sameen \& H Akbar.

\section{References}

1. Ramaprabha N \& Vasantha K (2012). Phytochemical and antibacterial activity of Calotropis procera (Ait). R Br. Flowers. Inter J of Pharmacol and Biosci 3(1): 1-6.

2. Mazid M, Khan TA \& Mohammad F (2011). Role of secondary metabolites in defence mechanisms of plants. Biol and Med 3(2): 232-249.

3. Irchhaiya R, Kumar A, Yadav A, Gupta N, Kumar S, Gupta N, Kumar S, Yadav V, Prakash A \& Gurjar H (2014). Metabolites in plants and its classification. World $J$ of Pharm and Pharmaceu Sci 4(1): 287-305.

4. Shinwari Z K (2010). Medicinal plants research in Pakistan. $J$ of Med Plants Res 4(3): 161-176.

5. Adnan M, Hussain J, Shah M T, Shinwari ZK \& Ullah F (2010). Proximate and nutrient composition of medicinal plants of humid and sub-humid regions in Northwest $J$ of Med Plants 4(4): 339-345.

6. Ghani A, Nadeem M, Ahmed M, Hussain M, Ikram M \& Imran M (2016). Spatial variations in nutritional an elemental analysis of MAKO (Solanum nigrum) 
collected from different tehsils of district Mianwali Pakistan. Sci Inter (Lahore) 28(6).

7. Baeshen NA \& Janse RK (2014). Complete sequences of organelle genomes from the medicinal plant Rhazya stricta (Apocynaceae) and contrasting patterns of mitochondrial genome evolution across asterids. Genomics 15.

8. Abudayeh, Z, Lamazian R, Sereda H, Chekman P, Khalifa I, Al-Azzam IA \& Hassouneh LKM (2016). Comparative study of amino acid composition in the seeds, pulp and rind from Citurllus colocynthis fruits. Inter $J$ of Pharmacog and Phytochem Res 8(3): 433-437.

9. Asif M, Akram M, Saeed T, Khan I, Naveed A, Riaz-Ur-Rehman M, Shah M A,Nazish K A \& Shaheen G (2011). Review paper carbohydrates. International Res $J$ of Biochem and Bioinform 1(1): 1-5.

10. Liu A G, Ford N A, Hu F B, Zelman K M, Mozaffarian D \& Kris-Etherton PM (2017). A healthy approach to dietary fats: understanding the science and taking action to reduce consumer confusion. Nutri J 16(53).

11. Madhu C, Krishna K M, Reddy KR, Lakshmi PJ \& Kelari EK (2017). Estimation of crude fiber content from natural food stuffs and its laxative activity induced in rats. Inter $J$ of Pharma Res and Health Sci 5(3): 1703-1706.

12. Dewis J \& Freitas F (1970). Physical and Chemical methods of soil and water analysis. Soils Bull 10: 32-63

13. Rhoades JD (1982). Aluminum solubility in organic soil horizons from northern and southern forested Watersheds. American J of Soil Sci 54: 399-37

14. Jackson ML (1962). Surface effects in a pulsed. AIChE J 8: 659-66.

15. AOAC (2000). Official methods of analysis $17^{\text {th }}$ ed., Official Analytical Chemists.Arlin-gton, VA, USA

16. Steel RGD \& Torrie JH (1980). Principles and procedures of statistics. A Biometrical Approach, 2. McGraw-Hill, New York.
17. Baloch, WB, Memon N, Rani M, Abbasi AR, Khan S, Memon A, Afridi HI \& Ullah L(2016). Nutritional composition of Rhazya stricta, A local medicinal plant of Kech Region, Pakistan. Rawat Med J 41(3).

18. Ghani A, Nadeem M, Ahmed M, Hussain M, Ikram M \& Imran M (2016). Spatial variations in nutritional an elemental analysis of MAKO (Solanum nigrum) collected from different tehsils of district Mianwali Pakistan. Sci Inter (Lahore) 28(6).

19. Ani PN \& Abel CH (2018). Nutrient, phytochemical, and antinutrient composition of Citrus maxima fruit juice and peel extract. Food 6(3): 653-658

20. Hussain J, Ullah R, Rehman N, Khan AL, Muhammad Z, Khan F U \& Anwar, S (2010). Endogenous transitional metal and proximate analysis of selected medicinal plants from Pakistan. $J$ of Med Plants Res 4(3): 267-270

21. Akpabio UD \& Ikpe EE (2013). Proximate composition and nutrient analysis of Aneilema aequinoctiale leaves. Asian Journal of Plant Sci and Res 3(2): 55-61.

22. Ooi D J, Iqbal S \& Ismail M (2012). Proximate composition, nutritional attributes and mineral composition of Peperomia pellucida L. (Ketumpangan Air) grown in Malaysia. Moleculesm 17:11139-11145

23. Dastagir G, Hussain H \& Rizvi MA (2013). Mineral composition of plants of family Zygophyllaceae and Euphorbiaceae. Pakistan Journal of Botany 46(3):887-

24. Kassegn AH \& Yildiz F (2017). Determination of proximate composition and bioactive compounds of the Abyssinian purple wheat, Cogent. Food and Agriculture 4(1).

25. Akpabio UD \& Ikpe EE (2013). Proximate composition and nutrient analysis of Aneilema aequinoctiale leaves. Asian J of Plant Sci and Res 3(2): 55-61.

26. Ani PN \& Abel CH (2018). Nutrient, phytochemical, and antinutrient 
composition of Citrus maxima fruit juice and peel extract. Food 6(3): 653-658

27. Hussain J, Ullah R, Rehman N, Khan AL, Muhammad Z, Khan FU \& Anwar, S (2010). Endogenous transitional metal and proximate analysis of selected medicinal plants from Pakistan. $J$ of Med Plants Res 4(3): 267-270

28. Kassegn AH \& Yildiz F (2017). Determination of proximate composition and bioactive compounds of the Abyssinian purple wheat, Cogent. Food and Agric 4(1).

29. Akpabio UD \& Ikpe EE (2013). Proximate composition and nutrient analysis of Aneilema aequinoctiale leaves. Asian J of Plant Sci and Res 3(2): 55-61.

30. Hussain J, Ullah R, Rehman N, Khan AL, Muhammad Z, Khan FU \& Anwar, S (2010). Endogenous transitional metal and proximate analysis of selected medicinal plants from Pakistan. $J$ of Med Plants Res 4(3): 267-270

31. Ghani A, Nadeem M, Ahmed M, Hussain M, Ikram M \& Imran M (2016). Spatial variations in nutritional an elemental analysis of MAKO (Solanum nigrum) collected from different tehsils of district Mianwali Pakistan. Sci Inter (Lahore) 28(6).

32. Pamela CC, Richard A H \& Denise RF (2005). Lippincotts illustrated Reviews Bio-chemistry 3rd ed., Lippincott Williams and Wilkins, Philadelphia, pp 335- 388.

33. Hussain J, Ullah R, Rehman N, Khan AL, Muhammad Z, Khan FU \& Anwar S (2010). Endogenous transitional metal and proximate analysis of selected medicinal plants from Pakistan. $J$ of Med Plants Res 4(3): 267-270

34. Kassegn AH \& Yildiz F (2017). Determination of proximate composition and bioactive compounds of the Abyssinian purple wheat, Cogent. Food and Agric 4(1).

35. Ani PN \& Abel CH (2018). Nutrient, phytochemical, and antinutrient composition of Citrus maxima fruit juice and peel extract. Food 6(3): 653-658. 